\title{
CONTEXTUAL TEACHING AND LEARNING METHOD IN STUDYING ARABIC
}

\author{
M. Ilham Muchtar \\ Universitas Muhammadiyah Makassar \\ Jl. Sultan Alauddin No.259, Gn. Sari, Rappocini, Makassar \\ Email: : ilham_em@yahoo.com
}

\begin{abstract}
The concept of Contextual Teaching and Learning teaching emphasizes the full student's activity both physically and mentally. Contextual Teaching and Learning considers that learning is not a memorizing activity, considering facts, demonstrating repetitious exercise but a process of experience in life in nature . Contextual Teaching and Learning in learning Arabic is able to improve students' learning achievement in learning Arabic because learners are increasingly eager to learn or have the confidence to know something that is not yet known so as to make learners is not depressed in teaching and learning process.
\end{abstract}

Abstrak. Konsep pembelajaran Contextual Teaching and Learning menekankan pada aktivitas siswa secara penuh, baik fisik maupun mental.Contextual Teaching and Learning memandang bahwa belajar bukanlah kegiatan menghafal, mengingat faktafakta,mendemonstrasikan latihan secara berulang-ulang semata akan tetapi proses berpengalaman dalam kehidupan nyatadi alam terbuka.Contextual Teaching and Learning dalam pembelajaran bahasa Arabdiyakinidapat meningkatkan prestasi belajar siswa dalam belajar bahasa Arab karena peserta didik semakin bersemangat belajar ataupun mempunyai kepercayaan diri untuk mengetahui sesuatu yang belum diketahui sehingga membuat peserta didik tidak tertekan dalam proses belajar mengajar.

Keywords: Contextual, Teaching, Learning

DOI: http://dx.doi.org/10.24239/jsi.v14i1.465.175-188 


\section{Introduction}

Learning is essentially a process of interaction between learners and their environment. Therefore, a change of behavior into a better direction occurs. In the interaction, there are internal factors coming from the individual, as well as external factors coming from the environment. Teaching method is one of the ways which is used by a teacher in establishing relationships with students during the process of teaching. Therefore, learning process does not place the teacher as the only source of knowledge (teacher-centered).

Each teacher is required to focus on the process of presenting the material. Therefore, a teacher should have creativity in teaching by using all kinds of methods and approaches that are aligned with the subject matter being taught. Improvising the variety of model and methods in the presentation of the material will have a positive impact to the increasing interest of students to learn, especially Arabic.

Ahmad Zayadi and Abdul Majid said that:

The term learning means as an effort to educate a person or a group of people through various efforts, strategies, methods and approaches toward the achievement of the goals that have been planned. ${ }^{1}$

Professional educators have double duties, as teachers and educators. Learning process is strongly influenced by the performance and methods used by educators in presenting a subject matter. A learning which is oriented towards mastering subject matter is considered to fail to produce active, creative, and innovative students. Students can only remember the lesson in short term, but forget to implement the substance of the subject in everyday life. Students do not have the competence to solve problems in the face of new situations. In other words, the

\footnotetext{
${ }^{1}$ Ahmad Sayadi and Abdul Majid, Desain Pembelajaran (Jakarta: Rineka Cipta, 2006). 8
} 
subject matter received in a school cannot be translated in daily life because it is only oriented to the results, not the learning process.

Teacher, as the main motivator of the learning process in a school, tends to use a conventional-behavioristic learning pattern, in the sense that he is monotonous in delivering the subject matter. What occurs is only a transfer of knowledge, where students tend to be passive in receiving lesson information. Teachers are also unable to maximize the use of instructional media as a means of support in the process of introducing the subject matter. As a result, students are only able to know the subject matter of learning.

Therefore, a meaningful learning approach is necessary, which focuses on the learning process rather than the learning outcomes. Since the essence of contextual learning is learning to discover meaning, there is a special paradigm about the meaning of learning in contextual learning.

In the context of learning Arabic in Indonesia, it appears that the applied especially at the secondary schools still refers to the traditional method that depends on the teaching of Arabic grammatical rules (nahw wa sarf). ${ }^{2}$ As a result, student has a good ability in reading and understanding the yellow books (classical books) in one hand, but on the other hand, he is still weak in communication in Arabic.

One of the learning strategies which is able to make students get involved in the learning atmosphere is through a Contextual Teaching-Learning (CTL) approach. As a learning strategy, a contextual approach does not only make students understand the explanation of the teacher, but also required them to experience by themselves. Therefore, the contextual

${ }^{2}$ Azhar Arsyad, Bahasa Arab Dan Metode Pengajarannya, 1st ed. (Yogyakarta: Pustaka Pelajar, 2003). 137 
learning model is developed with the aim that learning goes more productive and meaningful.

\section{Contextual Teaching and Learning (CTL) Method}

\section{The Definition of Contextual Teaching and Learning (CTL)}

The word contextual comes from the word context which means "relationship, context, atmosphere". Therefore, Contextual Teaching and Learning (CTL) means "a learning which relates to particular atmosphere. In general, contextual means "relevance, relationship, following the context, which brings goal, meaning and interest.

According to Wina Sanjaya, Contextual Teaching and Learning (CTL) is a learning approach which stressed on the process of involving students to find a matter being studied and connect it to the situation of real life. This in turn encourages students to implement it in their daily life. ${ }^{3}$

From the above definition, it can be concluded that Contextual Teaching and Learning is a learning concept that helps teachers to connect a subject matter being studied by students to their daily lifes so they can feel the meaning from every subject matter being studied and implement it in all aspects of life. Students acquire knowledge and skills from limited context gradually, and from the process of self-construction, so that learning will be meaningful. follows:

Contextual approach is based on the ideas of learning as

- Learning process

- Learning is not just memorizing. Students must construct knowledge in their minds.

${ }^{3}$ Wina Sanjaya, Strategi Pembelajaran Berorientasi Standar Proses Pendidikan (Jakarta: Kencana, 2006). 106 
- Learners learn from experience, and then note the meaningful patterns of new knowledge.

- Experts agree that one's knowledge is organized and reflects a deep understanding of a problem.

- Knowledge can not be separated into separate facts or propositions, but reflects the skills that can be applied.

- Humans have different levels in responding new situations.

- Learners need to get used to solve problems, find something useful for him, and wrestle with ideas.

- Learning process can change the structure of the brain. Changes in brain structure goes along with the development of knowledge and skill organization.

- Transfer of knowledge. Students learn from experiencing, not from:

- Someone's gift

- Skills and knowledge are gradually extended from a limited context

- It is necessary for students to know why they study and how they use those knowledge and skills

- Learning environment

- Effective learning starts from a student-centered learning environment.

- Teaching should focus on how learners use their new knowledge. Learning strategy is more important than result.

- Feedback is very important for learners, derived from a correct assessment process.

- Creating a learning community in the form of teamwork is important. 
Meanwhile, according to Almasdi ${ }^{4}$, broadly speaking, the steps of applying Contextual Teaching and Learning in the class are as follows:

- Develop thinking that children will learn more meaningfully by working alone, discovering and constructing their own new knowledge and skills.

- Implement as far as possible inquiry activities for all topics.

- Develop students' curiosity by asking questions.

- Create a learning community (learning in groups).

- Present the model as an example of learning.

- Make a reflection at the end of the meeting.

- Perform an actual assessment in various ways.

\section{Characteristics of Contextual Teaching and Learning}

$\begin{array}{ll}- & \text { Establishing a meaningful relationship } \\ \text { - } & \text { Performing significant activities } \\ \text { - } & \text { Self-study } \\ \text { - } & \text { Mutual cooperation } \\ \text { - } & \text { Critical and refective thinking } \\ \text { - } & \text { Nurturing student's personality } \\ \text { - } & \text { Achieving a high standard } \\ \text { - } & \text { Using authentic assessment }\end{array}$

\section{The Principles of Contextual Teaching And Learning}

\section{- Constructivism}

In the view of constructivism, learning strategies are more emphasized than learning outcomes, where teachers are directed to focus on the preparation of strategies, techniques and teaching methods. Therefore, teachers position themselves as teaching facilitators, and students build their own knowledge through the active involvement in the teaching and learning process.

\footnotetext{
${ }^{4}$ Almasdi, Pembelajaran Dalam Implementasi Kurikulum Berbasis Kompetensi, 1st ed. (Jakarta: Persada, 2006). 57
} 
- Inquiry

In this view, knowledge and skills acquired by the students are not the result of remembering a set of facts, but the results of finding themselves. A teacher must prepare the design of learning activities that is oriented towards discovering the meaning from the subject matter being taught. The cycle of inquiry comprises: Observation, Questioning, Making hypothesis, Collecting data.

As a conclusion, the steps of inquiry activity are as follows: formulating problems, observing, analyzing or presenting results in writing, drawings, reports, charts, tables, and others. And Communicating or presenting the work to other readers, classmates, teachers or audients

- Questioning

Questioning is one of the learning activities. Even, for students, questioning is one indicator of productive learning activities. This activity is very important because teachers will know the level of students' knowledge. Students will confirm what they knew or what they have not known. Teachers will direct special attention to the aspects of subject matter that students have not known yet.

In productive activity, questioning is useful for: exploring administrative and academic information; verifying students' understanding; generating students' response; knowing students' interest; knowing what students have known; focusing students' attention on what they want; encouraging much more questions from students; refreshing students' knowledge.

- Learning Community

This concept is directed in order that the existing learning is a process of cooperation between students. The knowledge they acquired is the result of teamwork established by the teachers. Through the interaction, students are expected to communicate their knowledge to their fellow group members, as well as solve 
jointly the problems. The teachers, based on this concept, are in a position to give and come up with a main problem to be discussed, and the students continue the study based on teacher's instructions. Learning Community also teach the students to recognize the differences either in terms of student's social background or their level of understanding one to another.

- Modelling

Modeling is a method of presenting the material based on a particular model or skill. This method is more widely used for practical matters and requires examples that are seen directly by students. In the contextual learning, teachers are not the only model. The teachers may involve students to model something based on the experience they know or bring in experts from outside, such as in field of astronomy, to learn how to use binoculars.

Many approaches are used in the learning process, and each approach has its own characteristics. This characteristic is related to what becomes a focus and emphasis in learning.

According to Udin Saefudin Sa'ud, ${ }^{5}$ contextual learning approach is a learning approach which is basen on students, thinking ability, activity, and student experience, and focuses on teacher, problem (personal, social, and environmental), technology such as media of teaching and learning resources.

With regard to the aspects of life and environment, this learning approach involves students, activity, experience and independence, as well as the context of life and the environment.

Every child has a tendency to learn new and challenging things. Therefore, learning for them is an effort to solve challenging problems. The teachers help the students to be able

\footnotetext{
${ }^{5}$ Udin Saefudin, Inovasi Pendidikan, ed. 1st (Bandung: Alfabeta, 2008). 32
} 
to link new experiences with the previous ones, and facilitate the students to be able to assimilate.

Therefore, the contextual teaching and learning approach emphasizes full student activities, both physically and mentally. Contextual Teaching and Learning considers that learning is not a activity of memorizing, remembering facts, demonstrating exercise repetitively, but a process of experience in life real. In Contextual Teaching and Learning learning, learning in open-air place is necessary to obtain information, verify the findings, and review them in the classroom.

Contextual Teaching and Learning (CTL) can improve students' learning achievement because students are increasingly eager to learn or have confidence to study the unknown so that they are not stressed in a learning process. This significantly affects students' achievement in school and can be applied in everyday life.

\section{The Concept CTL in Learning Arabic}

In Indonesia, Arabic is incorporated into a foreign language family. Therefore, for Indonesian students, learning Arabic can run effectively if applying certain strategies and methods, because theories on the method of learning Arabic is basically the same as the theories of language learning in general.

One of the models in learning Arabic which is expected to be an alternative in learning Arabic to Indonesian students is a Contextual Teaching and Learning (CTL) method.

Basically, as explained earlier, the Contextual Teaching and Learning method is a learning approach that emphasizes the process of full student engagement so that students can find the material learned and relate it to daily life situations or specific areas. Therefore, students can feel the meaning of each subject matter received and implement it in various aspects of life. 
In learning foreign languages, especially Arabic, full involvement of students in the learning process is very important because in learning the language, mutual interaction between instructor and students should be done. If a teacher of Arabic only focuses on the delivery of the material or involves students not fully, for example, by having them memorize a number of vocabularies (mufradat) dan Arabic grammar (nahwu), the result is also not optimal.

As it is known, experts in methodology of teaching Arabic to non-Arabs categorize Arabic skills into four skills: 1) Mahārah alIstimā' (listening skill), 2) Mahārah al-Qiraāah (reading comprehension), 3) Mahārah al-Hiwār (proficiency in conversation) and 4) Mahārah al-Kitābah (writing proficiency). All indicators of proficiency in Arabic can be achieved using Contextual Teaching and Learning approach.

For example, mahārah al-Istimā' (listening proficiency) is usually applied in the early stages of learning Arabic. Studying this skill is important because it will allow one to learn the next type of proficiency and enable direct communication between the speaker and the listener. ${ }^{6}$

To get directly involved in a communication, a teacher of Arabic should train the students and habituate them this mahärah al-Istimā' (listening proficiency). Therefore, teachers should first be active in speaking Arabic in the classroom so that students get used to hearing sentences in Arabic.

In the meantime, mahārah al-hiwār or speaking skills is a student's ability to express what he or she thinks to others verbally. This skill is important to be taught because it is the first step toward the next skill, namely reading and writing skills. In

${ }^{6}$ Abdullah al-Tawwab, I'dād Mu'allīm Al-Lughah Al-'Arabiyyah Li Ghair Al-Nātiqīna Bihā (Jakarta: Ma'had al-‘Ulūm al-Islāmiyah wa al-'Arabiyyah, 1986). 39 
addition, this skill allows a two-way communication between the speaker and the listener.

With regard to speaking proficiency, Arabic teachers should be able to master the techniques and methods of presenting speaking skills well, through a method of conversation (hiwār) or using such aids as images and pictures that learners can communicate with others through these images and pictures.

Meawhile, mahārah al-qirā'ah or reading skill is the ability to connect between speech and symbols of writing, and through that symbol he can express his thoughts and ideas. ${ }^{7}$

The advanced reader can perform his or her activities outside the classroom. Students also can still connect with the target language (Arabic) through magazines, books or Arabic newspapers. This fact clearly indicates that the teaching of reading is in order to develop reading comprehension. Thus, it is the duty of Arabic teachers to ensure that learning of reading skill becomes a fun experience for students.

To make students happy with reading texts, Arabic teachers should prepare Arabic reading books with different topics and different levels of difficulty, so students can train themselves to read the texts outside of study time.

Finally, Mahārah al-Kitabah or writing skill is the ability of a person to express what is in his or her mind through the composition of words in the form of writing by using appropriate sentences. According to an Arabic expert, Mahmud Kamil alNaqah, ${ }^{8}$ this skill is a means of written communication between an individual and others. With this skill, people will recognize other people's ideas in the past and the present day.

\footnotetext{
${ }^{7}$ Muhammad Abd al-Qadir Ahmad, Țuruq Ta'limm Al-Lughah Al'Arabiyyah (Cairo: Maktabah al-Nahḍah al-Mișriyyah, 1979). 108

${ }^{8}$ Mahmud Kamil al-Naqah, Asāsiyyah Ta'līm Al-Lughah Al-'Arabiyyah Fĩ Ghair Al-'Arab (Sudan: Ma’had Khartoum, 1978). 97
} 
Writing is a skill which is most rarely used in comparsion with four types of skills explained above. Only few graduates of educational institutions who write their work in Arabic, including students who studied in the course program of Arabic.

Speaking of the need and effort to prepare students into the real world, writing is the most difficult skill to adapt among the four other types of proficiency above, since students are required to present their ideas in the form of writing and correct language.

Based on the above explanations, the Contextual Teaching and Learning (CTL) approach model is an important alternative in learning Arabic, especially for Indonesian students.

\section{Conclusion}

As a conclusion, it can be said that student's learning process is strongly influenced by the performance and methods used by teachers in presenting a subject matter.

Second, a teacher should have creativity in teaching by using all kinds of methods and approaches that are aligned with the subject matter taught.

Third, Contextual Teaching and Learning (CTL) is a learning approach that emphasizes the full involvement of students in order to find the material learned and relate it to real life situations. Contextual Teaching and Learning can improve student's learning achievement because he is increasingly eager to learn or have the confidence to discover the unknown so that they are not depressed in learning process.

Fourth, Arabic proficiencies such as listening (al-istima), writing (al-kitabah), reading (al-qira'ah) conversation or speaking (al-hiwar) can be achieved by using Contextual Teaching and Learning approach (contextual learning). 


\section{Reference}

Sayadi, Ahmad and Abdul Majid. Desain Pembelajaran. Jakarta: Renika Cipta, 2006.

Almasdi, Pembelajaran dalam Implementasi Kurikulum Berbasis Kompetensi. Edisi pertama, First Edition. Jakarta: Persada Media, 2006.

Ahmad, Muhammad Abd al-Qadir, Țuruq Ta'limm al-Lughah al'Arabiyyah. Mesir: Maktabah al-Nahḍah al-Mișriyyah,1979.

Arsyad, Azhar, Bahasa Arab dan Metode Pengajarannya, First Edition; Yogyakarta: Pustaka Pelajar, 2003

Arsyad, Azhar, Dasar-dasar Penguasaan Bahasa Arab, Second Edition; Yogyakarta: Pustaka Pelajar, 2002

Arsyad, Azhar, Manajemen Pendidikan Bahasa Arab, Second Edition; Yogyakarta: Pustaka Pelajar, 2002

Badry, Kamal Ibrahim, al-Thuruq al-'Ammah fi Tadris al-Lughah al-Arabiyyah, Jakarta: Penerbit LIPIA, 1997

Dahlan, Juwairiyah, Metode Belajar Mengajar Bahasa Arab, First Edition; Surabaya: Usaha Nasional, 1992

Din Yati dan Mudjiono. Strategi Pembelajaran Inovatif Kontemporer: Suatu Tinjauan Konseptual Operasional, First Edition, Jakarta: PT. Bumi Aks,ra, 2006.

al-Naqah, Mahmud Kamil, Asasiyat Ta'lim al-Lughah al-'Arabiyyah fi Ghayri al-'Arab, Sudan: Ma'had Khartoum, 1978

Sanjaya, Wina, Strategi Pembelajaran Berorientasi Standar Proses Pendidikan, Jakarta: Kencana, 2006.

Saefudin, Udin, Inovasi Pendidikan, First Edition. Bandung: Alfabeta, 2008.

Sobroto, Suryo, Prooses Belajar Mengajar di Sekolah. Jakarta: Rnika Cipta, 2009. 
Vol. 14, No. 1 Juni 2017: 175-188

al-Tawwab, Abdullah, I'dad Mu'allim al-Lughah al-'Arabiyyah Li Ghayri al-Natiqina Biha, Jakarta: Ma'had al-'Ulum alIslamiyah wa al-'Arabiyyah, 1986.

Wena, Made, Strategi Pembelajaran Inovatif Kontemporer: Suatu Tinjauan Konseptual Operasional, First Edition. Jakarta: PT. Bumi Aksara, 2009. 